\title{
Knowledge, attitudes and practices in food safety and the presence of coagulase- positive staphylococci on hands of food handlers in the schools of Camaçari, Brazil
}

\author{
Lilian S. Soares, Rogeria C.C. Almeida*, Ellayne S. Cerqueira, Joelza S. Carvalho, Itaciara L. Nunes \\ Escola de Nutrição, Universidade Federal da Bahia, Av. Araújo Pinho, n³ 32, Canela, Salvador-Bahia, Cep: 40.110-160, Brazil
}

\section{A R T I C L E I N F O}

\section{Article history:}

Received 30 August 2011

Received in revised form

9 March 2012

Accepted 17 March 2012

\section{Keywords:}

Food handlers

Food safety knowledge

Coagulase-positive staphylococci

\begin{abstract}
A B S T R A C T
The aim of this study was to evaluate the level of knowledge, attitudes and practices in food safety and the presence of coagulase-positive staphylococci species on the hands of food handlers in the municipal schools of Camaçari, Bahia in northeast Brazil. This study was conducted in two stages. In the first stage, 166 food handlers were interviewed via a questionnaire to assess their food safety knowledge, attitudes and practices. In the second phase, the presence of coagulase-positive staphylococci species on the hands of food handlers was determined. The results indicated that most of the handlers had been trained (92.2\%), but the level of knowledge was insufficient; the average proficiency score was $<70 \%$ accuracy. Attitude received the highest scores, and no handler had a score below 50.0\%. Logistic regression analysis showed that the level of education and specific subject expertise of the handlers were associated with general knowledge about food safety. Food handler overall had positive attitudes on food safety with all scores above $50.0 \%$. Despite a high prevalence of training and positive attitudes about food safety, $53.3 \%$ of the hand samples showed the presence of coagulase-positive staphylococci. No associations were found between the knowledge attitudes and practices of food handlers and the presence of the pathogen on their hands. The results showed inadequate sanitary practices of food handlers, highlighting the need to review the current model for training food handlers and to improve accessibility to sinks and supplies to ensure proper hygiene.
\end{abstract}

(c) 2012 Elsevier Ltd. All rights reserved.

\section{Introduction}

Food-borne diseases have been increasing in recent years, with a greater impact on the health and economy of developing countries than developed countries (WHO, 2007). According to the World Health Organization, in 2005 alone, 1.8 million people died from diarrheal diseases, and most of these cases were attributed to the ingestion of contaminated food and drinking water.

Meals prepared and distributed in schools should receive special attention because the foods are intended for young children, a population with an increased risk for several diseases due to microbial pathogens in foods. To ensure high quality meals for students, catering services need to follow the regulations set forth by the Health Surveillance Committee. Despite the existence of specific regulations, the safety measures taken during school meal preparation are still inadequate, as most schools do not take into consideration the specific sanitary requirements needed for the

\footnotetext{
* Corresponding author. Tel.: +55 713283 8937; fax: +55 7132837705 .

E-mail address: rogeriac@ufba.br (R.C.C. Almeida).
}

various stages of food preparation (Santana, Almeida, Ferreira, \& Almeida, 2009).

In Brazil, the National School Feeding Program (NFP) was responsible in 2010 for the $\mathbf{4 5 . 6}$ million meals distributed in public schools to students. Currently this program provides the food supply for students (from day care institutions, elementary and high schools, and general education for youth and adults) enrolled in public and philanthropic schools (FNDE, 2009). For many students, these meals are the primary meal, and often the only meal consumed by students in a day (Brasil, 2009).

Good personal hygiene and sanitary handling practices at work are an essential part of any prevention program for food safety. Although the majority of food handlers have the skills and knowledge to handle food safely, human handling errors have been implicated in most outbreaks of food poisoning (Ehiri \& Morris, 1996; Greig, Todd, Bartleson, \& Michaels, 2007; Howes, Mcewen, Griffiths, \& Harris, 1996). The inappropriate handling of foods by the food service industry has been implicated in $97 \%$ of food poisoning cases (Greig et al., 2007; Howes et al., 1996). There is no indication that food-borne illnesses are diminishing.

Worldwide, numerous food-borne disease outbreaks in schools have been reported (Hutin et al., 1999; Nicholas et al., 2002), but the 
extent of these outbreaks has not been systematically described. In Brazil in 2005, schools were responsible for $11.6 \%$ of the documented food-borne diseases outbreaks noticed (Brasil, 2005).

Staphylococcus aureus is considered the third most important cause of food-borne diseases in the world (Normanno et al., 2005). There are two major aggravations to its presence: the toxins production and antimicrobial resistance. $S$. aureus produces heatstable enterotoxins with demonstrated emetic activity (SEs; SEA to SEE, SEG to SEI, SER to SET). According to the authors SEs are a main cause of food poisoning that occurs after ingestion of foods contaminated with $S$. aureus by improper handling and subsequent storage at elevated temperatures. Symptoms are of rapid onset and include nausea and violent vomiting, with or without diarrhea. The illness is usually self-limiting and only occasionally it is severe enough to warrant hospitalization (Argudín, Mendoza, \& Rodicio, 2010).

The main reservoir of staphylococci in humans is the nostrils, although staphylococci can also be found on hands. The microorganism is responsible for enormous variety of infections, such as subcutaneous and skin infections, osteomielites, pneumonias, abscesses, endocarditic and bacteremia (Gelatti, Bonamigo, Becker, \& d'Azevedo, 2009). The prevalence of the bacteria in the population is so high that it is likely impossible to completely eliminate them. However, hand washing has been identified as one of the most important ways to prevent the spread of food-borne diseases.

Three factors are playing major role in the occurrence of food poisoning with regard to food handlers: knowledge, attitude and practice (Sharif \& Al-Malki, 2010). Training programs are important for improving the knowledge of food handlers; however, more knowledge of food safety practices does not always lead to positive changes in food handling behaviors (Ansari-Lari, Soodbakhsh, \& Lakzadeh, 2010). Because of this, several studies on the knowledge, attitudes and practices of food handlers have been conducted in various parts of the world (Ansari-Lari et al., 2010; Bas, Ersun, \& Kivanç, 2006; Capunzo et al., 2005; Jevšnik, Hlebec, \& Raspor, 2008; Martins, Hogg, \& Otero, 2012; Seaman \& Eves, 2010). These works reinforce the importance of conducting a preliminary assessment of training needs and evaluating the effectiveness of training and indicate that the continuous education is needed to assure constantly a good hygienic quality of food.

The objectives of the present study were to evaluate the level of knowledge, attitudes and practices in food safety and the presence of coagulase-positive staphylococci species on hands of food handlers in the municipal schools of Camaçari in northeast Brazil.

\section{Material and methods}

We performed a descriptive, cross-sectional study of 90 public schools in Camaçari, Bahia in northeast Brazil. Forty-nine schools were located in the metropolitan area and 41 schools were located on the waterfront (ocean area). A total of 52.226 students attended these 90 schools in 2010. We assessed the knowledge, attitudes and practices of food handlers using a structured questionnaire.

A total of 169 handlers were registered in the schools of Camaçari, and 166 participated in interviews (a response rate of 98.2\%). Ninety-four handlers were from schools in the metropolitan area (response rate of $96.9 \%$ ), and 72 handlers were from schools on the waterfront (response rate of 100\%). Informed consent, previously approved by the Ethics Committee of the School of Nutrition of the Federal University of Bahia, was provided by each participant.

\subsection{Interviews}

We assessed the knowledge, attitudes and practices of food handlers using a structured questionnaire. The questionnaire was peer-reviewed and underwent a pilot study in 40 schools in a nearby town before the final version was distributed to food handlers. The questionnaire was read and completed by an interviewer in individual interviews. The data collection period occurred between June and November 2010.

The questionnaire was organized into the following five distinct parts: part 1: demographic information (such as gender, age, level of education, length of employment and participation in training); part 2: information about the employees' work satisfaction; part 3: knowledge about food safety; part 4: attitudes on food safety; and part 5: food hygiene practices.

The questions regarding employees' work satisfaction (part 2: work load, satisfaction with profession, fulfill the norms and rules, conditions to guaranteeing safety of the food, relationship between students and work team) were adapted from Jevšnik et al. (2008), and answers were graded on five levels of intensity, with one (1) indicating "strongly disagree" and five (5) indicating "totally agree".

The questions that addressed knowledge, attitudes and practices (parts 3, 4 and 5) were adapted from the work of Angelillo, Viggiani, Greco, and Rito (2001), Bolton, Meally, Blair, Mcdowell, and Cowan (2008) and Ansari-Lari et al. (2010).

The knowledge section (part 3) included 25 close-ended questions with three possible answers, "true", "false", and "do not know". These questions focused on issues regarding personal hygiene, cross contamination, diseases carried by food, microorganisms, temperature control and hygiene practices. For evaluation, we used a scale ranging between 0 and 25 points. Handlers that had a score equal to or less than 17 points were regarded to have "insufficient" knowledge and those that had scores equal to or greater than 18 points ( $\geq 70 \%$ accuracy) were considered to have "good" knowledge. The cut-off point for the analysis of the results was higher than that reported in other studies (Angelillo et al., 2001; Bas et al., 2006) because most handlers interviewed had already received some form of training.

The attitudes section of the questionnaire (part 4) aimed to determine the understanding of the handler about food safety and contained 16 questions that required three levels of answers, "agree", "disagree", and "do not know". The term attitudes was used according to Princeton University definition: "a complex mental state involving beliefs and feelings and values and dispositions to act in certain ways" (http://wordnet.princeton.edu/) (Sharif \& Al-Malki, 2010).

Handlers that answered 11 or fewer questions correctly were considered to have "insufficient" understanding, where as the handlers that answered 12 or more questions correctly were considered to have "good" understanding.

In section 5, the good hygienic practices of food handlers were evaluated and were assessed through self-reporting on personal hygiene and related food handling procedures. There were 20 questions with five levels of answers, "never", "seldom", "sometimes", "often", and "always". For each correct practice reported, one (1) point was awarded. Practices reported as sporadic (seldom, sometimes or often), even though correct, were not scored. For classification, we used the same criterion as that used for the other parts, i.e., $70 \%$ or more correct answers ( $n \geq 14$ points) were regarded as "good" practices.

\subsection{Data analysis}

The data obtained from the questionnaires were tabulated and analyzed statistically using SPSS software for Windows, version 13. We used multiple logistic regression analyses and two tests of association, Pearson's chi-square $\left(X^{2}\right)$ and Fisher's tests. Results with a $p$-value $<0.05$ were considered statistically significant. For analysis of association between variables and for logistic regression 
models, the levels of knowledge, attitudes and practices (KAP) were categorized as "good" ( $\geq 70 \%$ correct) or "insufficient" $(<70 \%$ correct). Responses of "do not know/do not remember" were considered incorrect.

Four models for logistic regression analysis were developed to identify the variables that impacted the results of interest. These models included the following: model 1, understood knowledge about food-borne disease; model 2, knowledge and attitudes of personal hygiene; model 3 , knowledge and attitudes about temperature control; and model 4, knowledge and attitudes of food hygiene in relation to practice. All models incorporated predictive variables, including age, education level, civil servant, length of employment and training, and the dependent variable was the general knowledge about food safety. $p$-values less than 0.05 were considered statistically significant.

\subsection{Assessment of work place practice and the presence of coagulase-positive staphylococci on hands}

\subsubsection{Assessment of work place practice}

Visual observations were performed in the kitchens to verify employee hygiene practice and food handler practices. The presence and position of washbasins with tap water were assessed with attention given to production flow and service. Additionally, the presence of soap, scrubbing-brush hands, and paper towels was evaluated.

\subsubsection{Sampling and laboratory procedures}

Forty-five food handlers, each from a different school, were chosen randomly to be sampled. Samples were aseptically collected using swabs moistened with $2 \mathrm{ml}$ of $0.85 \%$ saline solution. These swabs were rubbed onto the hands of food handlers during food preparation, both before and immediately after the distribution of meals, and transported to the laboratory in an insulated cold box filled with ice. In the laboratory, the swabs were vortexed (B. Braun Biotech International, Germany) for $30 \mathrm{~s}$, transferred to tubes containing trypticase soy broth in a class II biosafety cabinet (Labconco Corporation, Labconco Purifier Class IIb, Total Exhaust, model 36210-04, certified ISO 9002, Kansas City,MO, USA) Labconco model 36210 class BII, Brazil) and incubated for $24 \mathrm{~h}$ at $37^{\circ} \mathrm{C}$. A loop of liquid was removed from the cultures, streaked onto mannitol salt agar plates and incubated at $37^{\circ} \mathrm{C}$ for $24 \mathrm{~h}$. The colonies were identified macro- and microscopically (Gram staining) and by catalase and coagulase tests (Souza \& Santos, 2009). One S. aureus positive control (ATCC 25923) and one uninoculated negative control were used for each set of analyzed samples.

\section{Results}

Of the 166 food handlers who participated in this study, $98.2 \%$ were female. The mean age of participants was 44 (Standard Deviation $=8.4$ ), and ages ranged between 26 and 65 years. The mean length of employment was 7.4 years $(S D=6.0)$. Approximately half $(45.8 \%)$ of the food handlers did not have a middle school education (less than 8 years of education or illiterate), and $44.6 \%$ were civil servants (Table 1 ). Civil servants are workers that the government has pre-approved and, in general, have greater employment stability.

Results obtained in evaluation of the employees' work satisfaction (part 2) showed that $65.6 \%$ of the handlers affirmed that they would choose the same profession, $53.0 \%$ determined that the work load was adequate. Half of the handlers said that not all of the necessary conditions were provided in the work place for guaranteeing the safety of the food (Table 2).
Table 1

Demographic characteristics of food handlers employed in the schools of Camaçari, Brazil (part 1).

\begin{tabular}{|c|c|c|c|c|}
\hline Characteristics & $n$ & $\%$ & Mean \pm SD & Range \\
\hline \multicolumn{5}{|l|}{ Sex } \\
\hline Male & 3.0 & 1.8 & & \\
\hline Female & 163.0 & 98.2 & & \\
\hline \multicolumn{5}{|l|}{ Age (years) } \\
\hline $25-35$ & 28.0 & 16.9 & & \\
\hline $36-55$ & 120.0 & 72.3 & & \\
\hline $56-65$ & 18.0 & 10.8 & $43.9 \pm 8.4$ & $26-65$ \\
\hline \multicolumn{5}{|l|}{ Education } \\
\hline Illiterate & 2.0 & 1.2 & & \\
\hline $\begin{array}{r}\text { Elementary school } \\
\text { complete or not }\end{array}$ & 74.0 & 44.6 & & \\
\hline $\begin{array}{l}\text { Middle school } \\
\text { complete or not }\end{array}$ & 81.0 & 48.8 & & \\
\hline $\begin{array}{l}\text { High school or higher } \\
\text { education complete } \\
\text { or not }\end{array}$ & 9.0 & 5.4 & & \\
\hline \multicolumn{5}{|l|}{ Civil servant } \\
\hline No & 92.0 & 55.4 & & \\
\hline Yes & 74.0 & 44.6 & & \\
\hline \multicolumn{5}{|l|}{ Training course } \\
\hline Não & 13.0 & 7.8 & & \\
\hline Sim & 153.0 & 92.2 & & \\
\hline \multicolumn{5}{|l|}{$\begin{array}{l}\text { Length of employment } \\
\quad \text { (years) }\end{array}$} \\
\hline $0-4.9$ & 44.0 & 26.5 & & \\
\hline $5-9.9$ & 80.0 & 48.2 & & \\
\hline $10-30$ & 42.0 & 25.3 & $7.4 \pm 6.0$ & $0.1-30$ \\
\hline \multicolumn{5}{|l|}{$\begin{array}{l}\text { Ratio of students to food } \\
\text { handlers }\end{array}$} \\
\hline $10-120$ & 31.0 & 18.7 & & \\
\hline $121-350$ & 106.0 & 63.9 & & \\
\hline $351-950$ & 29.0 & 17.5 & $239 \pm 148.1$ & $14-922$ \\
\hline
\end{tabular}

The survey of the food handlers' knowledge (part 3) demonstrated a rate of $16.3(\mathrm{SD}=2.6)$, the equivalent of $65.2 \%$ correct answers. This rate was low, considering that most participants had already undergone previous food safety training. In the attitude evaluation (part 4), the average rate was $12.8(\mathrm{SD}=1.2$ ), which corresponded to $80.0 \%$ correct answers, and the lowest rate was 8.0 ( $50 \%$ correct answers). These results indicated that $56.6 \%$ of the food

Table 2

Assessment of employees' work satisfaction (part 2).

\begin{tabular}{|c|c|c|c|}
\hline \multirow[t]{2}{*}{ Statements } & \multicolumn{3}{|c|}{ Respostas \% ( $n)$} \\
\hline & Disagree & No matter & Agree \\
\hline $\begin{array}{l}1 \text { If you could choose the profession, } \\
\text { would choose the same one? }\end{array}$ & $29.0(48)$ & $5.4(9)$ & $65.6(109)$ \\
\hline $\begin{array}{l}2 \text { When you have personal trouble, } \\
\text { did you share it with your colleagues? }\end{array}$ & $36.7(61)$ & $15.0(25)$ & $48.3(80)$ \\
\hline $\begin{array}{l}3 \text { When you have personal trouble, did } \\
\text { you share it with your principal? }\end{array}$ & $44.6(74)$ & $15.0(25)$ & $40.4(67)$ \\
\hline $\begin{array}{l}4 \text { Did you always fulfill the norms and } \\
\text { rules of the principal? }\end{array}$ & $2.4(4)$ & $9.0(15)$ & $88.6(147)$ \\
\hline $\begin{array}{l}5 \text { Did you would leave this work, if they } \\
\text { offered something better to you in } \\
\text { another place? }\end{array}$ & $38,6(64)$ & $11.4(19)$ & $50.0(83)$ \\
\hline 6 The work load is adequate? & $40.4(67)$ & $6,6(11)$ & $53.0(88)$ \\
\hline $\begin{array}{l}7 \text { The team of the kitchen is respected } \\
\text { by the students? }\end{array}$ & $12.0(20)$ & $12.0(20)$ & $76.0(126)$ \\
\hline $\begin{array}{l}8 \text { The team of the kitchen is respected } \\
\text { by the teachers and other workers of } \\
\text { the school? }\end{array}$ & $10.8(18)$ & $11.4(19)$ & $77.8(129)$ \\
\hline $\begin{array}{l}9 \text { The work place provides all the necessary } \\
\text { conditions to guaranteeing safety of } \\
\text { the food? }\end{array}$ & $50.0(83)$ & $10.8(18)$ & $39.2(65)$ \\
\hline $\begin{array}{l}10 \text { The meals served in the school did not } \\
\text { represent health risk to the students. }\end{array}$ & $13.8(23)$ & $5.4(9)$ & $80.7(134)$ \\
\hline
\end{tabular}


Table 3

Assessment of food safety knowledge of food handlers in the schools of Camaçari, Brazil (part 3).

\begin{tabular}{|c|c|c|c|}
\hline \multirow[t]{2}{*}{ Statements } & \multicolumn{3}{|c|}{ Responses \% (n) } \\
\hline & Right & Wrong & Do not know/remember \\
\hline 1 Washing hands before work reduces the risk of food contamination. & $97.6(162)$ & $2.4(4)$ & $0.0(0)$ \\
\hline 2 Using gloves while handling food reduces the risk of food contamination. & $89.2(148)$ & $10.2(17)$ & $0,6(1)$ \\
\hline 3 Proper cleaning and sanitization of utensils increase the risk of food contamination. & $75.3(125)$ & $24.7(41)$ & $0.0(0)$ \\
\hline 4 Eating and drinking in the work place increase the risk of food contamination. & $68.7(114)$ & $27.1(45)$ & $4.2(7)$ \\
\hline 5 Food prepared in advance reduces the risk of food contamination. & $76.4(127)$ & $22.4(37)$ & $1.2(2)$ \\
\hline 6 Reheating cooked foods can contribute to food contamination. & $93.4(155)$ & $6.0(10)$ & $0.6(1)$ \\
\hline 7 Washing utensils with detergent leaves them free of contamination. & $44.0(73)$ & $54.8(91)$ & $1.2(2)$ \\
\hline $\begin{array}{l}8 \text { Children, healthy adults, pregnant women and older individuals are at equal risk } \\
\text { for food poisoning. }\end{array}$ & $24.7(41)$ & $72.9(121)$ & $2.4(4)$ \\
\hline 9 Typhoid fever can be transmitted by food. & $44.6(74)$ & $11.4(19)$ & $44.0(73)$ \\
\hline 10 AIDS can be transmitted by food. & $86.1(143)$ & $7.9(13)$ & $6.0(10)$ \\
\hline 11 Bloody diarrhea can be transmitted by food. & $88.0(146)$ & $5.4(9)$ & $6.6(11)$ \\
\hline 12 Abortion in pregnant women can be induced by food-borne disease. & $29.5(49)$ & $47.6(79)$ & $22.9(38)$ \\
\hline 13 Salmonella is among the food-borne pathogens. & $63.3(105)$ & $1.8(3)$ & $34.9(58)$ \\
\hline 14 Hepatitis A virus is among the food-borne pathogens. & $37.3(62)$ & $24.1(40)$ & $38.6(64)$ \\
\hline 15 Staphylococcus is among the food-borne pathogens. & $43.4(72)$ & $5.4(9)$ & $51.2(85)$ \\
\hline $\begin{array}{l}16 \text { Swollen cans may contain the microorganism, Clostridium botulinum, which } \\
\text { causes botulism. }\end{array}$ & $81.9(136)$ & $1.2(2)$ & $16.9(28)$ \\
\hline 17 Microbes are in the skin, nose and mouth of healthy handlers. & $80.1(133)$ & $16.9(28)$ & $3.0(5)$ \\
\hline 18 Clean is the same as sanitized. & $62.1(103)$ & $32.5(54)$ & $5.4(9)$ \\
\hline $\begin{array}{l}19 \text { Cross contamination is when microorganisms from a contaminated food are } \\
\text { transferred by the food handler's hands or kitchen utensils to another food. }\end{array}$ & $94.0(156)$ & $1.8(3)$ & $4.2(7)$ \\
\hline 20 Freezing kills all the bacteria that may cause food-borne illness. & $63.3(105)$ & $33.7(56)$ & $3.0(5)$ \\
\hline 21 The correct temperature for storing perishable foods is $5{ }^{\circ} \mathrm{C}$. & $50.6(84)$ & $14.5(24)$ & $34.9(58)$ \\
\hline 22 Hot, ready-to-eat food should be kept at a temperature of $65^{\circ} \mathrm{C}$. & $58.4(97)$ & $13.3(22)$ & $28.3(47)$ \\
\hline 23 Contaminated foods always have some change in color, odor or taste. & $16.3(27)$ & $82.5(137)$ & $1.2(2)$ \\
\hline 24 Raw vegetables are at higher risk of contamination than undercooked beef. & $61.4(102)$ & $34.3(57)$ & $4.2(7)$ \\
\hline 25 During infectious disease of the skin, it is necessary to take leave from work. & $98.2(163)$ & $0.6(1)$ & $1.2(2)$ \\
\hline
\end{tabular}

handlers did not know that $S$. aureus is a pathogenic microorganism that is responsible for food-borne disease (part 3, question number 15 , Table 3 ). On the other hand, $98.2 \%$ of the food handlers recognized that it is necessary to take leave from work during cases of infectious skin disease (part 3, question number 25, Table 3), and $80.1 \%$ knew that microbes can be found in the skin, mouth and nose of healthy food handlers (part 3, question number 17, Table 3).

Almost all of the food workers were aware of the critical role of general sanitary practices in the work place, such as hand washing (97.6\% correct answers), using gloves (89.2\% correct answers) and proper cleaning of the instruments (75.3\% correct answers) (Table 3). Most of the participants (75.3\%) failed to select the correct answer for the question about high-risk groups for food poisoning (Table 3).

In the questions about hand hygiene and personal health (part 4, questions 2, 7, 10 and 16), the food handlers achieved scores equal to or higher than $96.4 \%$, demonstrating a good level of knowledge and attitude about food safety (Table 4). In the evaluation of selfreported practices, the average value was $14(\mathrm{SD}=2.8)(70.0 \%$ correct answers), and values ranged between 4.0 (20\%) and 18.0 (90\%). In the evaluation of hand hygiene (part 5, questions 2, 6 and 7, Table 5), high scores (89.1, 90.4 and $89.1 \%$ correct answers, respectively) were observed.

Logistic regression results are shown in Table 6 . The models tested demonstrated significant differences $(p<0.05)$ with the exception of model 2 . These statistics differences were observed only when we used the explanatory variable education level. The models demonstrated that the food handler with higher specific knowledge had a better knowledge about food safety. For example, in the analysis of model 1 the results indicates that the food handlers that presented good level of knowledge about risk groups for food-borne diseases had an adjusted OR of $11.0\left(\mathrm{Cl}_{95}, P=0.000\right)$, that means 11.0 times more possibilities to have a good level of knowledge on food safety when compared with food handler with insufficient level of knowledge for this variable.
This analysis presents some limitation due to the use of three levels of answers, although the questionnaire had been evaluated in a pilot study. The model for questionnaire adopted was adapted from the work of Angelillo et al. (2001), to work out the comparison between the data obtained.

Analyzing the association between other variables, the results showed significant differences $(p<0.05)$ for civil servants and the knowledge level; knowledge about food-borne diseases and knowledge about food safety; employees' work satisfaction and civil servants (Fig. 1). Age does not have a statistic significant effect on the results obtained, although in the case of the knowledge of civil servants the analysis indicated a statistic difference.

In the second stage of the study there are some limitations due to the relatively small number of food handler used to compare presence/absence of coagulase-positive staphylococci in hands. Although, 97.8\% ( $n=44)$ of the food handlers that participated in the second stage of the study had attended food safety training programs, $53.3 \%(n=24)$ had coagulase-positive staphylococci on their hands; a prevalence of the microorganism was observed in the samples collected during food preparation and distribution of meals (Table 7). Considering that distribution is the last stage in the process of food preparation, this indicates that the presence of infected food handler can raise the risk of food contamination.

The statistical analysis of the activity of the food handlers and the presence or absence of coagulase-positive staphylococci on the hands (Table 7) showed that although the presence of the microorganism was observed in the samples collected during both preparation and distribution (22.2 and $20.0 \%$, respectively), there was no significant difference between these variables $(p=0.935)$. With regard to the work place, we observed a greater percentage of samples that were negative for the microorganism on the hands of food handlers from schools located in the metropolitan area of Camaçari (37.8\% of the samples), but this association was not statistically significant $(p=0.094)$. 
Table 4

Assessment of food safety attitudes of food handlers in Camaçari schools.

\begin{tabular}{|c|c|c|c|}
\hline \multirow[t]{2}{*}{ Statements } & \multicolumn{3}{|c|}{ Responses \% $(n)$} \\
\hline & Right & Wrong & Do not know/remember \\
\hline 1 Well-cooked foods are free of contamination. & $16.9(28)$ & $82.5(137)$ & $0.6(1)$ \\
\hline 2 Proper hand hygiene can prevent food-borne diseases. & $96.4(160)$ & $3.6(6)$ & $0.0(0)$ \\
\hline $\begin{array}{l}3 \text { When cleaning products are closed, they can be stored with cans and } \\
\text { jars of food that are also closed. }\end{array}$ & $84.9(141)$ & $14.5(24)$ & $0.6(1)$ \\
\hline $\begin{array}{l}4 \text { Raw and cooked foods should be stored separately to reduce the risk } \\
\text { of food contamination. }\end{array}$ & $98.8(164)$ & $0.6(1)$ & $0.6(1)$ \\
\hline $\begin{array}{l}5 \text { It is necessary to check the temperature of refrigerators/freezers } \\
\text { periodically to reduce the risk of food contamination. }\end{array}$ & $95.8(159)$ & $2.4(4)$ & $1.8(3)$ \\
\hline 6 Defrosted foods can be refrozen. & $94.0(156)$ & $5.4(9)$ & $0.6(1)$ \\
\hline 7 The health status of workers should be evaluated before employment. & $98.8(164)$ & $0.6(1)$ & $0.6(1)$ \\
\hline 8 The best way to thaw a chicken is in a bowl of cold water. & $72.3(120)$ & $23.5(39)$ & $4.2(7)$ \\
\hline $\begin{array}{l}9 \text { Wearing masks is an important practice to reduce the risk of food } \\
\text { contamination. }\end{array}$ & $91.6(152)$ & $7.8(13)$ & $0.6(1)$ \\
\hline $\begin{array}{l}10 \text { Wearing gloves is an important practice to reduce the risk of food } \\
\text { contamination. }\end{array}$ & $97.6(162)$ & $2.4(4)$ & $0.0(0)$ \\
\hline $\begin{array}{l}11 \text { Wearing caps is an important practice to reduce the risk of food } \\
\text { contamination. }\end{array}$ & $98.2(163)$ & $1.8(3)$ & $0.0(0)$ \\
\hline $\begin{array}{l}12 \text { The ideal place to store raw meat in the refrigerator is on the } \\
\text { bottom shelf. }\end{array}$ & $12.7(21)$ & $86.7(144)$ & $0.6(1)$ \\
\hline 13 Eggs must be washed immediately after delivery. & $26.5(44)$ & $69.9(116)$ & $3.6(6)$ \\
\hline 14 Dish towels can be a source of food contamination. & $97.0(161)$ & $3.0(5)$ & $0.0(0)$ \\
\hline $\begin{array}{l}15 \text { Knives and cutting boards should be properly sanitized to prevent } \\
\text { cross contamination. }\end{array}$ & $98.6(164)$ & $0.6(1)$ & $0.6(1)$ \\
\hline $\begin{array}{l}16 \text { Food handlers who have abrasions or cuts on their hands should } \\
\text { not touch foods without gloves. }\end{array}$ & $97.6(162)$ & $2.4(4)$ & $0.0(0)$ \\
\hline
\end{tabular}

Table 8 demonstrates that $75.0 \%$ of the staphylococci-positive samples were from food handlers with insufficient knowledge of food safety; however, this association was not statistically significant. It was observed that $57.1 \%$ of the food handlers who did not have contaminated hands were civil servants, but this association was not statistically significant (Table 7).

\section{Discussion}

This investigation provides valuable information about the level of knowledge, attitudes, and practices in food safety and the presence of coagulase-positive staphylococci on hands of food handlers. An important result from this study was that almost all respondents claimed that they washed their hands before using gloves and answered correctly that washing hands before work reduces the risk of food contamination. These important hygiene measures practiced by almost all the food handler are very encouraging. Hand washing has been shown to reduce the risk of diarrhea disease in child care institutions (Xavier, Oporto, Silva, Silveira, \& Abrantes, 2007) and could certainly do the same in the schools. Despite the reported hand washing, however many employees' had their hands contaminated by coagulase-positive staphylococci. These results are important considering that staphylococcal infections and related diseases are increasing (Stepanovic et al., 2005) and neither the use of gloves nor even the practice of hand washing completely eliminated the risk of cross contamination. However, combining the use of gloves with proper hand washing can reduce the risk of cross contamination (Montville, Chen, \& Schaffner, 2001).

Table 5

Assessment of food hygienic practices of food handlers in the schools of Camaçari, Brazil.

\begin{tabular}{|c|c|c|}
\hline \multirow[t]{2}{*}{ Statements } & \multicolumn{2}{|c|}{ Responses \% (n) } \\
\hline & Right & Wrong \\
\hline $\begin{array}{l}1 \text { Do you use gloves during the distribution of unpacked foods? If you never use gloves, } \\
\text { go to question } 3 .\end{array}$ & $70.5(117)$ & $29.5(49)$ \\
\hline 2 Do you wash your hands properly before using gloves? & $89.1(148)$ & $10.9(18)$ \\
\hline 3 Do you wear an apron while working? & $66.3(110)$ & $33.7(56)$ \\
\hline 4 Do you wear a cap while working? & $92.2(153)$ & $7.8(13)$ \\
\hline 5 Do you wear a mask when you distribute unwrapped foods? & $1.8(3)$ & $98.2(166)$ \\
\hline 6 Do you wash your hands properly before touching raw foods? & $90.4(150)$ & $9.6(16)$ \\
\hline 7 Do you wash your hands properly after touching raw foods? & $89.1(148)$ & $10.9(18)$ \\
\hline 8 Do you eat or drink in your work place? & $34.3(57)$ & $65.7(109)$ \\
\hline 9 Do you wear nail polish when handling food? & $86.1(143)$ & $13.9(23)$ \\
\hline 10 Do you taste the food with your hand cupped? & $72.3(120)$ & $27.7(46)$ \\
\hline 11 Do you prepare a meal in advance (i.e., from one shift to another)? & $80.1(133)$ & $19.9(33)$ \\
\hline $\begin{array}{l}12 \text { Do you use cutting boards of different colors or do you sanitize a cutting board between } \\
\text { preparation of raw foods and cooked foods? }\end{array}$ & $79.1(131)$ & $20.9(35)$ \\
\hline 13 Do you thaw food outside the refrigerator (i.e., room temperature)? & $41.0(68)$ & $59.0(98)$ \\
\hline 14 Do you check the shelf life of foods at the time of delivery? & $82.2(136)$ & $17.8(30)$ \\
\hline 15 Do you check the packing integrity of foods at the time of delivery? & $89.0(148)$ & $11.0(18)$ \\
\hline 16 Do you check the internal temperature of meat with a thermometer? & $0.0(0)$ & $100(166)$ \\
\hline 17 Do you use leftover food? & $86.7(144)$ & $13.3(22)$ \\
\hline 18 Do you properly clean the food storage area before storing new products? & $75.3(125)$ & $24.7(41)$ \\
\hline 19 Do you use the sanitizer when washing service utensils (plates, mugs and spoons)? & $42.8(71)$ & $57.2(95)$ \\
\hline 20 Do you use the sanitizer when washing fruits? & $48.2(80)$ & $51.8(86)$ \\
\hline
\end{tabular}


Table 6

Results from the logistic regression analyses.

\begin{tabular}{|c|c|c|c|}
\hline Variable & OR adjusted & Confidence interval (95\%) & $p$-value \\
\hline \multicolumn{4}{|l|}{ Model 1} \\
\hline Knowledge about risk groups for food-borne diseases & 11.0 & $3.5-34.6$ & 0.000 \\
\hline Knowledge about HIV as a food-borne disease & 13.7 & $2.3-75.9$ & 0.004 \\
\hline Knowledge about hepatitis virus as a food-borne pathogen & 3.1 & $1.2-8.1$ & 0.019 \\
\hline Knowledge about Staphylococcus as a food-borne pathogen & 4.6 & $1.7-12.0$ & 0.002 \\
\hline Knowledge about Clostridium versus swollen cans & 10.1 & $1.6-62.4$ & 0.013 \\
\hline Knowledge about microorganisms versus the health of food handlers & 17.5 & $2.6-117.4$ & 0.003 \\
\hline Level of education & 3.8 & $1.8-8.2$ & 0.001 \\
\hline \multicolumn{4}{|l|}{ Model $2^{\mathrm{a}}$} \\
\hline Knowledge about gloves use & 2.9 & $0.6-14.5$ & 0.185 \\
\hline Knowledge about eat and drink in the work place & 2.1 & $0.8-5.2$ & 0.130 \\
\hline Attitude about masks use & 0.3 & $0.1-1.4$ & 0.144 \\
\hline Practice about eat and drink in the work place & 0.5 & $0.2-1.3$ & 0.143 \\
\hline Level of education & 4.1 & $1.8-9.0$ & 0.001 \\
\hline \multicolumn{4}{|l|}{ Model 3} \\
\hline Knowledge about freezing versus microorganisms & 4.3 & $1.7-11.0$ & 0.002 \\
\hline Knowledge about refrigeration temperatures & 3.3 & $1.5-7.4$ & 0.003 \\
\hline Level of education & 3.5 & $1.8-7.1$ & 0.000 \\
\hline \multicolumn{4}{|l|}{ Model 4} \\
\hline $\begin{array}{l}\text { Knowledge about food contamination versus attributes of foods } \\
\text { that may indicate contamination }\end{array}$ & 5.0 & $1.9-12.9$ & 0.001 \\
\hline Knowledge of the shelf life & 4.2 & $1.3-13.9$ & 0.020 \\
\hline Level of education & 3.4 & $1.7-6.7$ & 0.000 \\
\hline
\end{tabular}

${ }^{a}$ Model 2 did not show significant differences $(p>0.05)$.

One of the main reasons for this concern is the fact that recently the isolation of methicillin-resistant $S$. aureus (MRSA) strains from several food producing animals has been reported. Furthermore, after processing, infected food handlers may contaminate foods with MRSA during further preparation (Boer et al., 2009).

In the present study important practices were observed that may negatively impact food safety, such as absence of disposable soap and towels and also the lack of exclusive wash areas for hand hygiene (only two schools had an exclusive lavatory). The presence of a washbasin in the processing area is of primary importance to ensure adequate hygienic practices of food handlers since failures in hygienic procedures have been associated as the cause of foodborne disease outbreaks (Greig et al., 2007; Todd, Michaels, Smith, Greig, \& Bartleson, 2010).

Although, the knowledge of proper hand hygiene is not the only procedure to be applied in training. The training must be multidimensional, including visual acknowledgments of awareness by the handlers, supervisors and colleagues and also provision of the necessary resources. These approaches will reinforce the beliefs and behaviors of the food handlers.

Unlike the knowledge about food-borne diseases, our findings show that the question about AIDS was answered correctly by $86.1 \%$ of the food handlers, demonstrating that the propagation of the AIDS health campaigns reached the population in general. The unfamiliarity about the groups of food-borne diseases risks also must be mentioned, especially since its one of the biggest concerns in the attendance to this clientele. These results corroborate with recent work of Ansari-Lari et al. (2010), where half of the respondents did not know if Salmonella, hepatitis A and the B viruses, and Staphylococcus caused food-borne disease.

Reinforcing the need to adopt multidimensional approach, some studies have demonstrated that the extensive knowledge of the correct practices for hand hygiene do not necessarily results in the appliance of these methods because of the work place barriers

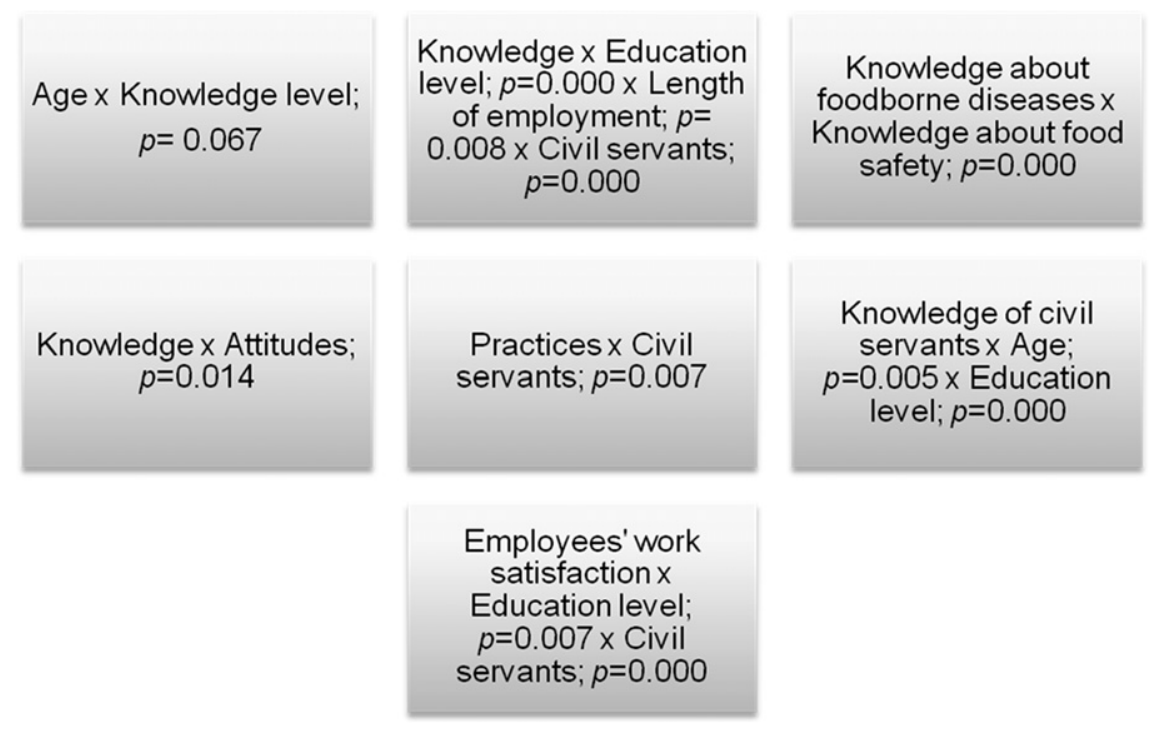

Fig. 1. Bivaried analysis between knowledge, attitudes, practices and other variables (Pearson's chi-square). 
Table 7

Bivaried analysis between presence of coagulase-positive staphylococci on hands of food handlers and other variables.

\begin{tabular}{|c|c|c|c|c|}
\hline \multirow[t]{2}{*}{ Variable } & \multicolumn{2}{|c|}{ Coagulase-positive staphylococci } & \multirow{2}{*}{$\begin{array}{l}\text { Total } \\
n / \%\end{array}$} & \multirow[t]{2}{*}{$p$-value } \\
\hline & $\begin{array}{l}\text { Positive } \%^{\mathrm{a}} \\
\left(n / \%^{\mathrm{b}}\right)\end{array}$ & $\begin{array}{l}\text { Negative \%a } \\
\left(n / \%^{\mathrm{b}}\right)\end{array}$ & & \\
\hline \multicolumn{5}{|l|}{ Civil servant } \\
\hline No & $54.2(13 / 28.9)$ & $42.9(9 / 20.0)$ & $22 / 48.9$ & $0.148^{\mathrm{d}}$ \\
\hline Yes & $45.8(11 / 24.4)$ & $57.1(12 / 26.7)$ & $23 / 51.1$ & \\
\hline \multicolumn{5}{|l|}{ Activity of food handler } \\
\hline Distribution of meals & $37.5(9 / 20.0)$ & $42.9(9 / 20.0)$ & $18 / 40.0$ & $0.935^{\mathrm{c}}$ \\
\hline Preparation of meals & $41.7(10 / 22.2)$ & $38.1(8 / 17.8)$ & $18 / 40.0$ & \\
\hline Hygiene or cleanliness & $20.8(5 / 11.1)$ & $19.0(4 / 8.9)$ & $9 / 20.0$ & \\
\hline \multicolumn{5}{|l|}{ Work place } \\
\hline $\begin{array}{l}\text { Schools of the } \\
\text { metropolitan area }\end{array}$ & $58.3(14 / 31.1)$ & $81.0(17 / 37.8)$ & $31 / 68.9$ & $0.094^{\mathrm{d}}$ \\
\hline Schools near the sea & $41.7(10 / 22.2)$ & $19.0(4 / 8.9)$ & $14 / 31.1$ & \\
\hline
\end{tabular}

a $\%$ represents the frequency of the variable.

b \% represents the frequency of positive or negative samples related to number of samples collected (45).

c Pearson's $X^{2}$ test.

d Fisher's test.

\section{Table 8}

Bivaried analysis between data from knowledge, attitudes and practices of food handlers and the presence of coagulase-positive staphylococci on hands.

\begin{tabular}{|c|c|c|c|c|}
\hline \multirow[t]{2}{*}{ Variable } & \multicolumn{2}{|c|}{ Coagulase-positive staphylococci } & \multirow{2}{*}{$\begin{array}{l}\text { Total \% } \\
(n)\end{array}$} & \multirow[t]{2}{*}{$p$-value } \\
\hline & $\begin{array}{l}\text { Positive } \%^{\mathrm{a}} \\
\left(n / \%^{\mathrm{b}}\right)\end{array}$ & $\begin{array}{l}\text { Negative } \%^{\mathrm{a}} \\
\left(n / \%^{\mathrm{b}}\right)\end{array}$ & & \\
\hline \multicolumn{5}{|l|}{ Knowledge } \\
\hline $\begin{array}{l}\text { Insufficient } \\
\quad(\leq 17 \text { right answers })\end{array}$ & $75.0(18 / 40)$ & $61.9(13 / 29)$ & $31 / 69$ & $0.266^{\mathrm{c}}$ \\
\hline $\begin{array}{l}\text { Good } \\
\qquad(\geq 18 \text { right answers })\end{array}$ & $25.0(6 / 13)$ & $38.1(8 / 18)$ & $14 / 31$ & \\
\hline \multicolumn{5}{|l|}{ Attitudes } \\
\hline $\begin{array}{l}\text { Insufficient } \\
\quad(\leq 11 \text { right answers })\end{array}$ & $25.0(6 / 13)$ & $9.5(2 / 4.4)$ & $8 / 18$ & $0.168^{c}$ \\
\hline Good ( $\geq 12$ right answers) & $75.0(18 / 40)$ & $90.5(19 / 42)$ & $37 / 82$ & \\
\hline \multicolumn{5}{|c|}{ Practices } \\
\hline $\begin{array}{l}\text { Insufficient } \\
\quad(\leq 13 \text { right answers })\end{array}$ & $58.3(14 / 31)$ & $38.1(8 / 18)$ & $22 / 49$ & $0.145^{\mathrm{c}}$ \\
\hline Good ( $\geq 14$ right answers) & $41.7(10 / 22)$ & $61.9(13 / 29)$ & $23 / 51$ & \\
\hline \multicolumn{5}{|c|}{ Personal hygiene } \\
\hline $\begin{array}{l}\text { Insufficient } \\
\quad(\leq 6 \text { right answers })\end{array}$ & $54.2(13 / 29)$ & $42.9(9 / 20)$ & $22 / 49$ & $0.324^{\mathrm{c}}$ \\
\hline Good (7-9 right answers) & $45.8(11 / 24)$ & $57.1(12 / 27)$ & $23 / 51$ & \\
\hline
\end{tabular}

(Clayton \& Griffith, 2004; Green et al., 2006). These barriers come from the work staff, including inhibitory attitudes of supervisors and colleagues, time pressures and/or lack of staff, as well as structural factors, such as facilities and accessibility to supplies. Therefore, the training of food handlers should be carried out covering social, environmental and organizational factors, and with greater focus on risk perception that may lead to unsafe practices (Coleman, Griffith, \& Botterill, 2000; Ehiri, Morris, \& Mcewen, 1997; Rennie, 1995).

Finally, the findings about educational level demonstrated that improper food handling practices are not always a result of a low level of education; improper handling may simply be reflective of a dominant practice, and certain unsafe practices might not necessarily occur if the circumstances under which the practice has taken root are addressed. Thus, we agree with many researchers and specialists that argue that a chain of personal, social and work place factors influences the practices of the food handler, and these factors need to be investigated in order for a change in behavior to take place (Green et al., 2007). It seems that more specific training courses should be planned for food handlers. The courses should include an evaluation process to ensure the effectiveness. It is therefore necessary to evaluate the impact of the knowledge acquired in food safety training to develop methodologies to properly train food handlers.

\section{Acknowledgments}

The authors thank CAPES for scholarship support.

\section{Appendix A. Supplementary material}

Supplementary data related to this article can be found online at doi:10.1016/j.foodcont.2012.03.016.

\section{References}

Angelillo, I. F., Viggiani, N. M. A., Greco, R. M., \& Rito, D. (2001). HACCP and food hygiene in hospital: knowledge, attitudes, and practices of food services staff in Calabri, Italy. Infection Control Hospital Epidemiology, 22, 1-7.

Ansari-Lari, M., Soodbakhsh, S., \& Lakzadeh, L. (2010). Knowledge, attitudes and practices of workers on food hygienic practices in meat processing plants in Fars, Iran. Food Control, 21, 260-263.

Argudín, M. A., Mendoza, M. C., \& Rodicio, M. R. (2010). Food poisoning and Staphylococcus aureus enterotoxins. Toxins, 2, 1751-1773.

Bas, M., Ersun, A. S., \& Kivanç, G. (2006). The evaluation of food hygiene knowledge, attitudes, and practices of food handler's in food businesses in Turkey. Food Control, 17, 317-322.

Boer, E., Zwartkruis-Nahuis, J. T. M., Wit, B., Huijsdens, X. W., Neeling, A. J., Bosch, T. C., et al. (2009). Prevalence of methicillin-resistant Staphylococcus aureus in meat. International Journal of Food Microbiology, 134, 52-56.

Bolton, D. J., Meally, A., Blair, I. S., Mcdowell, D. A., \& Cowan, C. (2008). Food safety knowledge of head chefs and catering managers in Ireland. Food Control, 19 291-300.

Brasil. (2009). FNDE. Fundo Nacional de Desenvolvimento da Educação. Alimentação escolar. Brasília. Available at http://www.fnde.gov.br/home/index.jsp/ arquivo=alimentação_escolar.html\#consultas [acess in 20 out 2009].

Brasil. Ministério da Saúde. (2005). Secretaria de Vigilância Sanitária. Boletim Eletrônico Epidemiológico. Ano $5 n^{\circ}$ 6. Available at http://portal.saude.gov.br/portal/ arquivos/pdf/ [acess in November 2009].

Capunzo, M., Cavallo, P., Boccia, G., Brunetti, L., Buonomo, R., \& Mazza, G. (2005) Food hygiene on merchant ships: the importance of food handlers' training. Food Control, 16, 183-188.

Clayton, D. A., \& Griffith, C. J. (2004). Observation of food safety practices in catering using notational analysis. British Food Journal, 106, 211-227.

Coleman, P., Griffith, C., \& Botterill, D. (2000). Welsh caterers: an exploratory study of attitudes towards safe food handling in the hospitality industry. International Journal of Hospitality Management, 19, 145-157.

Ehiri, J. E., \& Morris, G. P. (1996). Hygiene training and education of food handlers: does it work? Ecology of Food and Nutrition, 35, 243-251.

Ehiri, J. E., Morris, G. P., \& Mcewen, J. (1997). Evaluation of a food hygiene training course in Scotland. Food Control, 8, 137-147.

FNDE. (2009). Fundo Nacional do Desenvolvimento da Educação, Alimentação Escolar -Histórico. Available at http://www.fnde.gov.br/index.php/ae-historico [acess in november 2011].

Gelatti, L. C., Bonamigo, R. R., Becker, A. P., \& d'Azevedo, P. A. (2009). Staphylococcus aureus resistentes à meticilina: disseminação emergente na comunidade. Anais Brasileiros de Dermatologia, 84, 501-516.

Green, L. R., Radke, V., Mason, R., Bushnell, L., Reimann, D. W., Mack, J. C., et al. (2007). Factors related to food worker hand hygiene practices. Journal of Food Protection, 70, 661-666.

Green, L. R., Selman, C. A., Radke, V., Ripley, D., Mack, J. C., Reimann, D. W., et al. (2006). Food worker hand washing practices: an observation study. Journal of Food Protection, 69, 2417-2423.

Greig, J. D., Todd, E. C., Bartleson, C. A., \& Michaels, B. S. (2007). Outbreaks where food workers have been implicated in spread of foodborne disease, part 1 . Description of the problem, methods, and agents involved. Journal of Food Protection, 70, 1752-1761.

Howes, M., Mcewen, S., Griffiths, M., \& Harris, L. (1996). Food handler certification by home study: measuring changes in knowledge and behavior. Dairy Food Environmental Sanitation, 16, 737-744.

Hutin, Y. J., Pool, V., Cramer, E. H., Nainam, O. V., Weth, J., Williams, I. T., et al. (1999). A multistate, foodborne outbreak of hepatitis A. New England Journal Medicine, $340,595-602$.

Jevšnik, M., Hlebec, V., \& Raspor, P. (2008). Food safety knowledge and practices among food handlers in Slovenia. Food Control, 19, 1107-1118. 
Martins, R. B., Hogg, T., \& Otero, J. G. (2012). Food handlers' knowledge on food hygiene: the case of a catering company in Portugal. Food Control, 23, 184-190.

Montville, R., Chen, Y., \& Schaffner, D. (2001). Gloves barriers to bacterial crosscontamination between hands to food. Journal of Food Protection, 64, 845-849.

Nicholas, D. A. M. D. Mackinnon, L., Rowe, S. M., Bean, N. H., Griffin, P. M., \& Mead, P. S. (2002). Foodborne disease outbreaks in United States schools. The Pediatric Infectious Disease Journal, 21, 623-628.

Normanno, G., Firinu, A., Virgilio, S., Mula, G., Dambrosio, A., Poggiu, A., et al. (2005). Coagulase-positive staphylococci and Staphylococcus aureus in food products marketed in Italy. International Journal of Food Microbiology, 98, 73-79.

Rennie, D. M. (1995). Health education models and food hygiene education. Journal of Royal Society Health, 115, 75-79.

Santana, N. G., Almeida, R. C. C., Ferreira, J. S., \& Almeida, P. F. (2009). Microbiologica quality and safety of meals served to children and adoption of good manufacturing practices in public school catering in Brazil. Food Control, 20, 255-261.

Seaman, P., \& Eves, A. (2010). Perceptions of hygiene training amongst food handlers, managers and training providers - a qualitative study. Food Control, 21, 1037-1041.
Sharif, L., \& Al-Malki, T. (2010). Knowledge, attitude and practice of Taif University students on food poisoning. Food Control, 21, 55-60.

Souza, P. M., \& Santos, D. A. (2009). Microbiological risk factors associated with food handlers in elementary schools from Brazil. Journal of Food Safety, 29, 424-429. Stepanovic, S., Dakic, I., Morrison, D., Hauschild, T., Ježek, P., Petrâš, P., et al. (2005). Identification and characterization of clinical isolates of members of the Staphylococcus sciuri group. Journal of Clinical Microbiology, 43, 956-958.

Todd, E. C. D., Michaels, B. S., Smith, D., Greig, J. D., \& Bartleson, C. A. (2010) Outbreaks where food workers have been implicated in the spread of foodborne disease. Part 9. Washing and drying of hands to reduce microbial contamination. Journal of Food Protection, 73, 1937-1955.

World Health Organization. (2007). Food safety and food-borne illness. Fact sheet No. 23. Available at http://wwwwho.int/mediacentre/factsheets/fs237/en/ (Reviewed March).

Xavier, C. A. C., Oporto, C. F. O., Silva, M. P., Silveira, I. A., \& Abrantes, M. R. (2007) Prevalência de Staphylococcus aureus em manipuladores de alimentos das creches municipais da cidade do Natal-RN. Revista Brasileira de Análises Clínicas, $39,165-168$ 